\title{
Reflections on the Core Problems of Chinese Marxism, Marxism Modernization and Marxism Popularization
}

\author{
Zhangbin, Linyu \\ Fujian Polytechnic of Information Technology, Fuzhou, Fujian, 350003
}

\begin{abstract}
Seventeen sessions of Fourth Plenary Session proposed integration promote Chinese Marxism, Marxism modernization and Marxism popularization. It has practical and far-reaching strategic significance. This paper around the core problems of Chinese Marxism, Marxism modernization and Marxism popularization made some thinking. It revealed the background, defined the connotation of them. Last, put forward the methodology.
\end{abstract}

KEYWORD: Chinese Marxism; Marxism modernization and Marxism popularization; the reason; connotation; methodology

\section{THE REASON OF THE "THREE" SUBJECT OF MARXISM PUT FORWARD}

Proposition of sinicization of marxism is put forward by MAO zedong in the $30 \mathrm{~s}$ and answer, he pointed out that "the great strength of marxism-leninism lies in it is associated with concrete revolutionary practice of all countries. To say the communist party of China, is to learn to apply the theory of marxismleninism to China's specific environment." Characteristics of "left China to talk about marxism, just abstract empty marxism. Therefore, the sinicization of marxism, to make it in its every performance with Chinese characteristics, that said, according to the characteristics of China's application of it, as the whole party to understand and be solved the problem of". 534 [1] although marxism itself has internal contains some elements of The Times and the mass, but the main emphasis is marxism spatial dimension indigenization, nationalization. Times are always moving forward, ecstasy, and the state of the union and party are also profound changes, the marxist theoretical character is advancing with The Times, in the new historical stage, under the new historical conditions, the central committee of the communist party of China clearly, complete the sinicization of marxism was proposed, era, the popular major topics, has a strong theoretical and practical significance.

About the proposition of "marxism era", in fact, li dazhao and others have been put forward, and the fourth plenary session of the party's seventeenth in expression, on the basis of past formally put forward to promote the sinicization of marxism, era, the popular integration, clearly put forward the important thesis of marxist era,

Plenary session from three dimensions of space, time, and the audience for the development of marxism in China put forward more specific requirements, is to enrich and develop marxist sinicization of connotation and denotation, both with pertinence and far-reaching strategic significance. "Our party has put forward" three "of marxism this important thesis emphasis on the development and innovation of marxism, is to make the development and innovation of marxism in today's more effectively guide the construction of China's modernization." 17 [2] to avoid the party in ruling the repeated treatment in the history of revolution and marxist dogmatism and subjectivism, and the cause of revolution and socialist construction cause serious damage and loss. Today we emphasize on the Chinese characteristic socialism theory system of self-confidence, confidence and roads, but selfconfidence is not arrogance, self-confidence is not equal to wishful thinking, self-confidence should be general communist party members and the masses of the people from the heart, and to do the three confidence, you must keep up with the trend of the era development, constant innovation and development, and constantly promote marxism sinicization, age and a higher degree of popularity. Therefore, it is necessary for us to subdivide the sinicization of marxism, age and popularization of make a clear definition of the connotation and essence of requirement, reveals the significance of 
marxist "three", in order to better promote the "three" of marxism.

\section{THE CONNOTATION AND ESSENCE OF "THREE" OF MARXISM}

Marxist "' three 'one body two wings", Chinese is a "one", age and popularization for the "two wings".' appoaches to contracted, clearly express all essence of sinicization of marxism." [3] in mainland China, Chinese is the core, the age is, the power, the popularization is the goal.

\subsection{Sinicization of marxism}

The sinicization of marxism after the segmentation, should focus on nationality, namely marxism is concrete, rather than the abstract, marxism must be through the national form to achieve, "reveals the nationality of Chinese characteristics, Chinese style, Chinese style is the essential requirement of marxism". [4] 29 sinicization of marxism is to use marxist world outlook and methodology principle and China and the spatial dimension of "the specific environment" (refers to the development of China's international environment, era background and the development trend of the world) and the "special conditions" (China's national conditions is the particularity of China's social nature, social situation and the particularity of nationality problems), the combination of analysis for solving the practical problems of the Chinese revolution, construction and reform, and according to Chinese actual conversion. Integrating theory with practice, is the only way to realize the sinicization of marxism. In advancing the great process of sinicization of marxism, the communist party of China will be creatively marxist basic principle combined with China's concrete practice, realize the two historic leaps of marxism sinicization, and formed MAO zedong thought and theory system of socialism with Chinese characteristics two great theoretical achievements. New century new stage, China's reform and opening up has entered the deep waters, is in a crucial stage, should not only face to face with many years accumulation or put aside all hard tough problems, and from the traditional, national conditions, the party sentiment changes brought historic opportunity and unprecedented challenge, which requires the party and the country should continue to encourage the practice of the masses, but also at the national level to strengthen the top-level design. Top-level design scientific and reasonable or not, fundamentally determines the crucial stage of reform and opening up can be smoothly, determines the realization of the great revival of the Chinese dream, the reality of the top-level design theory of demand, more urgent demands further the nationalization of marxism, constantly put forward in accordance with the theoretical innovation of China's actual, put forward the deepening of reform for the third plenary session of the eighteenth indicate the direction and theoretical source.

\subsection{Era of marxism}

Marxism era is defined on the time dimension, is the key marxist theory to eternal vitality, is a marxist the pursuit of the mission. Therefore, interpret the connotation of marxist era should aim at its openness and keep pace with The Times, namely, marxism is inclusive, open and continuous development of innovation, is not self sealing, old doctrines, marxism era only for there is no complete, reflect the adhere to marxism and the development of the marxist dialectical unification. Marxist era, requires us to use the marxist stand, viewpoint and method, deep insight into the current development trend, profound grasp nine basic features of the primary stage of socialism accurately seize the reform essentials and timely sum up the masses of the people in the reform practice of fresh experience, make the sublimation for the new theory to guide the new practice, and in response to push and solve all kinds of new contradictions and difficulties of marxist theory of advancing with The Times, make marxism theory, coruscate gives new vitality, as deng xiaoping points out: the scientific socialism is the development of the real struggle, marxismleninism, MAO zedong thought is in actual fighting. We... Doesn't make marxism to stay in a few decades ago, or the judgment on the individual level of more than one hundred years ago. So we said it over and over again, emancipate the mind, is to use the basic principles of marxism-leninism and MAO zedong thought, study new situations, solve new problems. "[5] 179

\subsection{The popularization of marxism}

Idea about the popularization of marxism, the earliest in 17th report, "the popularity of the Chinese characteristic socialism theory system activity, promote the popularization of marxism of contemporary China." [6] and the popularization of marxism is the most can reflect the fundamental attribute of the marxism. First of all, it reflects the value orientation is a research, to apply marxism thought and method to study and solve various problems of public, so the research is popular; Second, it is a kind of expression of popularization of marxism, which is popular language to give expression to profound truth. Popularization of marxism is the marxist stand, viewpoint and method is applied to solving specific problems of the masses, and the theory of marxism in the process from abstract to concrete, from deep to shallow, a 
few scholars academic monopoly to the popular, comprehend and grasp. In contemporary China, to promote the popularization of marxism, is the most basic including deng xiaoping theory and "three represents" important thought, the concept of scientific development, the Chinese dream and other major strategic thoughts, the system of theories of socialism with Chinese characteristics of popularization, to give practical feature of the theory of socialism with Chinese characteristics, national characteristics and times features. The essence of the popularization of marxism of contemporary China's characteristic socialism theory system of popularization. It includes three aspects: the contents of a practice characteristic is to face the real problem and solution actual problem, close to the masses of the people thought the actual; 2 it is national characteristics is in conformity with the Chinese traditional culture, for the Chinese people happy, accord with Chinese habit and accepting way; Three is the era characteristic is must be consistent and historical process of China's modernization, reflect the progress of science and culture of the new reality. Catch the ideal of socialism with Chinese characteristics in construction of belief education as the core, is the purpose of popularization of marxism of contemporary China, is also the most fundamental purpose of the popularization of socialism with Chinese characteristics. The effective measure of popularization of marxism of contemporary China: the people like it or not; Profound lasting degree; The difficult problem to solve more or less; People is the problem of oral or firmly; The degree of social climate better; The degree of social harmony; Propaganda and education has more or less benefited range; Popularization degree of continuous power.

\section{IMPLEMENTATION OF MARXIST METHODOLOGY OF "THREE"}

Methodology to solve the problem is the key to realize "three" of marxism, the masses of the people as a system of theories of socialism with Chinese characteristics of sinicization and popularization, times of the audience is subject to look at, is close to the people's thought reality, close to the people's concern, close to the people to accept the thought characteristic of ideological education, close to the people's thinking and language to realize the sinicization of theoretical system of socialism with Chinese characteristics, the popularization and age. Therefore, in a sense, popular is the basic way of marxism and The Times, in terms of specific methods can take the following some ways and methods:

\subsection{Construction reflects marxist "three" subject system and teaching material system of the latest achievements of colleges and universities.}

College students is the social group with high cultural level, and with the popularity of higher education in China, the number of this group has increased dramatically, become the backbone of the construction of socialism with Chinese characteristics, they are learning in the process of the system of theories of socialism with Chinese characteristics for the propaganda, popularization and promotion of the glorious mission that the theory of socialism with Chinese characteristics, which requires the college ideological education workers should strengthen its own theoretical system of marxist study and discussion, combining the reality of society, continuously ground, keep building fully reflect, popularization era, the latest achievements in adapting marxism to the subject system and teaching material system, driving system of theories of socialism with Chinese characteristics into the teaching materials, into the classroom, in the mind.

\subsection{Set up various forms of propaganda and education platform}

Efforts to broaden the propaganda and education platform. The traditional print media, film and television, exhibition board, banners and major Internet portals, QQ space, new media such as blogs, microblogging, micro letter, new social platform, building activity union, form rich and lively new platform for the publicity and education, make the scientific theory into the thousands. All departments and units to develop an administrative publicity with high political quality, business team, to grasp the direction of the publicity and education activities, adhere to the socialist core values as the basic spiritual bond, strengthen to the identity of socialist core values, to prevent and overcome in order to cater to public taste tendency of entertainment and philistinism.

\subsection{Positive innovation language style system}

Positive expression style innovation, actively adapt to the language habit of the public, to some of the arcane theory colloquial, life, vivid, through "public philosophy", "learning with philosophy", "theory of hot face to face" let the people can understand and read the text illustrated theory of learning, through public welfare advertisement, publicity advanced typical and popular forms, in the form of popularization in the popularization of scientific theory, improve the scientific theory accomplishment in the popularization, reach the purpose of raise the level of the whole nation culture and overall quality. 


\subsection{To strengthen the construction of culture, adhere to cultural innovation}

Stepping up its construction of socialist culture with Chinese characteristics, adhere to the various forms of cultural innovation. Encouraged to create a large number of rich cultural connotation of socialism with Chinese characteristics, a simple story, essay, play this kind of popular literary works for the people, in a lively atmosphere in the artistic charm of popularizing marxism, Held various forms of lectures, readings, through the project introduction, make theory focused, concise, reach the purpose of the integrity of marxism popularization system.

\subsection{To solve practical problems and difficulties of the people}

Financially aware than really do work, adhere to the mass line in the work, using the marxist stand, viewpoint and method, practical solution of the actual difficulties of the masses of the people, and in order to strengthen the popularization of marxism practical function, this is the most obvious way to promote theoretical popularization, immediate. Facts speak louder than words, also can put under the guidance of theories of socialism with Chinese characteristics, for the people "of the results obtained for centralized display method, promote the" three "is deeply rooted in the hearts of the people of the theory of marxism reveals marxist" three "objective value.

\section{ACKNOWLEDGEMENT}

Humanities and social science research projects in fujian province department of education, ideological and political theory course teaching research initiative, JA11427S).

\section{REFERENCES}

[1] Mao zedong. Mao zedong selections: the second volume, people's publishing house

[2] Li haiqing. Marxist "three": the value of realization of socialist modernization with Chinese characteristics. Journal of the central committee of the communist party of China party school journal, 2013 (1).

[3] Zhang kuilian. The relationship of marxist "three". Kwangmyong - guangming daily http://www.gmw.cn 2011-11-21

[4] Chenwangsong. Marxism, popularization era, the connotation and the dialectical relationship of. Journal of neijiang normal college, 2013 (9)

[5] Deng xiaoping. Stick to the four cardinal principles. Selected works of deng xiaoping: volume 2. People's publishing house, 1994.

[6] $\mathrm{Hu}$ jintao. Holding the great banner of socialism with Chinese characteristics, strive for the comprehensive construction affluent society new victory. People's publishing house, 2007.

\section{ABOUT AUTHOR}

1. Zhangbin (1975.03 ), male, Minhou, Fujian, Fujian Polytechnic of Information Technology, the lecturer, master degree, mainly engaged in socialist theory and ideological and political education research.

2. Linyu (1973.07 ), female, Fuzhou, Fujian, Fujian Polytechnic of Information Technology, assistant researcher, bachelor's degree. Mainly engaged in the study of party affairs management. 